\title{
Beta diversity patterns of Bromeliaceae growing on rocky cliffs within the Atlantic Forest in southern Brazil
}

\author{
Edilaine Andrade Melo ${ }^{1 *}$ \& Jorge Luiz Waechter ${ }^{2}$ (i) \\ ${ }^{1}$ Universidade Federal do Rio Grande do Sul, Programa de Pós-Graduação em Botânica, Laboratório de \\ Fitoecologia e Fitogeografia, Porto Alegre, RS, Brasil \\ ${ }^{2}$ Universidade Federal do Rio Grande do Sul, Departamento de Botânica, Laboratório de Fitoecologia e \\ Fitogeografia, Porto Alegre, RS, Brasil \\ *Corresponding author: Edilaine Andrade Melo, e-mail: edilainemel_bio@yahoo.com.br
}

MELO, E. A., WAECHTER, J. L. Beta diversity patterns of Bromeliaceae growing on rocky cliffs within the Atlantic Forest in southern Brazil. Biota Neotropica. 20(1): e20190846. http://dx.doi.org/10.1590/1676-0611-BN-2019-0846

\begin{abstract}
In recent years there has been increasing attention in patterns of $\beta$-diversity and mechanisms related to variations in species composition. In this study, we evaluated beta diversity patterns of bromeliads growing on cliffs immersed in Atlantic Forest. We hypothesized that the species composition varies according to the spatial scale, inferring that there is a replacement of species influenced mainly by environmental factors. The study was carried out on sandstone cliffs included in contiguous but distinct vegetation formations: Evergreen and Seasonal forests. Twenty-four vertical rocky outcrops were sampled. The spatial variation in species composition was evaluated by two $\beta$-diversity components, turnover and nestedness. Multivariate analysis and variation partitioning were performed to distinguish niche and stochastic processes. We recorded 26 bromeliad species and a significantly higher contribution of turnover explaining beta diversity. Environmental factors affect $\beta$-diversity patterns of Bromeliaceae. However, individually, the environmental predictors do not explain the data variation. Environmental variations spatially structured, and spatial variables determinate the dissimilarity in the composition of bromeliads on cliffs. Thus, our results revealed that both environmental and spatial effects can act together to define the floristic composition of rock-dwelling bromeliad communities.
\end{abstract}

Keywords: Sandstone outcrops, bromeliads, evergreen forest, seasonal forest, Niche Theory, Neutral Theory.

\section{Padrões de diversidade beta de Bromeliaceae crescendo em falésias rochosas dentro da Mata Atlântica no sul do Brasil}

Resumo: Nos últimos anos tem havido uma crescente atenção em relação aos padrões de diversidade $\beta$ e aos mecanismos relacionados às variações na composição de espécies. Neste estudo, nós avaliamos os padrões de diversidade beta de bromélias crescendo em escarpas rochosas imersas em matriz de Floresta Atlântica. Hipotetizamos que a composição das espécies varia de acordo com a escala espacial, inferindo que há uma substituição de espécies influenciadas principalmente por fatores ambientais. O estudo foi realizado em escarpas areníticas inseridas em formações vegetacionais contíguas, mas distintas: Florestas Ombrófila e Estacional. Vinte e quatro afloramentos rochosos verticais foram amostrados. A variação espacial na composição de espécies foi avaliada por dois componentes de diversidade $\beta$, turnover e aninhamento. Análise multivariada e particionamento da variação foram realizados para distinguir processos de nicho e estocásticos. Registramos 26 espécies de bromélias, com uma contribuição significativamente maior do turnover explicando a diversidade beta. Os fatores ambientais afetam os padrões de diversidade $\beta$ de Bromeliaceae, no entanto, individualmente, esses preditores não explicam a variação dos dados. Assim, variações espaciais e variações ambientais espacialmente estruturadas determinam a dissimilaridade na composição de bromélias nas escarpas avaliadas. Desse modo, tanto os fatores ambientais determinísticos quanto os efeitos espaciais podem atuar em conjunto para definir a composição florística das comunidades de bromélias que se estabelecem sobre rochas.

Palavras-chave: Afloramentos areníticos, bromélias, floresta ombrófila, floresta estacional, Teoria de Nicho, Teoria Neutra. 


\section{Introduction}

Investigating patterns of species distribution is one of the essential objectives of ecology and a challenge to understand the complex set of processes driving the structure of communities. The variation in species composition among communities ( $\beta$-diversity) can be related to the influence of several biotic and abiotic conditions (Cottenie 2005). The use of beta diversity measures based on dissimilarity between samples or communities can clarify several questions about the distribution of species, allowing inferences on environmental effects, and the influence of spatial or random factors on the establishment of species (Baselga 2010).

Previous studies have identified that both deterministic and stochastic processes, widely discussed by the Niche Theory and the Neutral Theory, respectively, can act at different spatial scales to define species composition and diversity patterns (Ricklefs $\&$ Schluter 1995, Duarte et al. 2010, Segre et al. 2014). Niche-based processes assume that the establishment of a species is limited by environmental filters (Grinnell, 1917; Legendre \& Legendre, 1998), while neutral processes assume that dispersion acts as one of the main mechanisms in determining the diversity patterns (Hubbell 2001). The structure of communities is thus determined by two distinct processes acting on the regional pool of species (Hubbell 2001, Gaston \& Chown 2005).

Theoretical approaches related to the effects of spatial and environmental filters may also reveal interesting patterns when applied in plant communities growing on rocky cliffs associated with highly heterogeneous and diversified ecosystems. This is the case of the Brazilian Atlantic Forest, a well-known hotspot of biodiversity, and thus highly important for conservation purposes (Ribeiro et al. 2009, Mittermeier et al. 2015). There are many gaps in the understanding of how local and regional diversity on cliffs is maintained and the degree of connection between them along in the forest.

The Brazilian Atlantic Forest comprises noticeably heterogeneous vegetation, including several related ecosystems, such those occurring on rock outcrops (Scarano 2002, Leão et al. 2014). The vegetation on rock outcrops, including on cliffs, in general, differ from the surrounding forest matrix mainly due to absent or incipient soils, and microclimatic conditions resulting from high insolation and low water availability (Porembski \& Barthlott 2000). In Southern Brazil, cliffs are embedded in different landscapes of the Atlantic Forest, which in this region is classified into three main types: Evergreen Forest (tropical rain forest), Araucaria Forest (subtropical Araucaria forest) and Seasonal Forest (tropical deciduous and semideciduous forest) (Veloso et al. 1991, IBGE 2012).

The Bromeliaceae family has been highlighted as one of the most frequent and important family in rocky environments, especially for the ecological role in the succession process, acting as nursery plants, forming islands that increase water availability and mechanical support for other species (Porembski et al. 1997, 1998, Porembski 2005, Rocha et al. 2014, de Paula et al. 2016). Furthermore, in Atlantic Forest, they present great ecological importance resulting from the many interactions with other organisms (Martinelli et al. 2008, Givnish et al. 2011, Machado et al. 2016).

The influence of the forest matrix on the composition and diversity of bromeliads growing on rocky outcrops has recently been described (Melo $\&$ Waechter 2018). However, patterns of species distribution and theoretical approaches related to the effects of spatial and environmental variables on the composition of these communities have not yet been addressed.
Although studies evaluating plant communities on rocky outcrops have expanded in recent years, including in Brazil (Ferreira et al. 2014, Saraiva et al. 2015, do Carmo et al. 2016, Machado et al. 2016, de Paula et al. 2019), floristic composition and community structure on cliffs are still little known.

Here, we evaluated the effects of environmental and spatial variables in plant communities growing on rocky cliffs, identifying the variations in composition along in two distinct forest typologies: Evergreen Forest and Seasonal Forest. The objective of this study was to evaluate beta diversity patterns of bromeliads growing on cliffs immersed in Atlantic Forest and to identify the mechanisms that act in the structure of these communities. Thus, we investigate the following questions: (i) How do beta diversity of rock-dwelling Bromeliaceae vary in a transition zone between Evergreen and Seasonal Atlantic Forest? (ii) Which are the spatial and environmental variables affecting composition variations of bromeliads on rocky cliffs? (iii) What amount of variation in the floristic composition can be attributed to the environment (deterministic), space (stochastic), and both processes?

We expected that (i) the composition of species varies according to the spatial scale and between forest types, meaning that there is a substitution of species along with space, corroborating studies in rocky outcrop and with other vegetation components in this phytogeographic domain (Bergamin et al. 2017, Silva Mota et al. 2018); (ii) Species turnover is influenced by climatic factors related to transition zone, like the variation in temperature and precipitation, demonstrating that rocky outcrops also influenced by regional environmental filters, as is the distribution of epiphytic bromeliad species along the Atlantic forest (Fontoura et al. 2012). (iii) Beta diversity is explained mainly by spatially structured environmental variables so that both deterministic and stochastic processes are important in explaining the composition of epiplithic bromeliad communities, as has been observed in other studies conducted in rocky habitats (Sarthou et al. 2017, Silva Mota et al. 2018).

\section{Material and Methods}

\section{Study Area}

The study area is located in the Southern Region of Brazil, comprising the northeast of Rio Grande do Sul and the southeast of Santa Catarina states (roughly between latitudes $29^{\circ}$ and $30^{\circ} \mathrm{S}$ ). Our study was conducted on cliffs, environments characterized as the exposed and steep face of the rocky outcrop (Larson et al. 2000). All the investigated cliffs are sandstone outcrops inserted in two different types of Atlantic Forest, the Evergreen and Seasonal physiognomies.

The studied rocky outcrops are located at low elevations (below $200 \mathrm{~m}$ ) between the coastline of the Atlantic Ocean and the abrupt slopes of the Serra Geral Mountain Range, in a heterogeneous landscape now mostly comprising some disturbed habitats, like roadsides, meadows for cattle rise, or secondary vegetation.

The entire study area has a humid subtropical climate (Cfa), according to the Köppen classification system, with hot summers and abundant rainfall throughout the year. The regional climate has a mean annual temperature of around $18^{\circ} \mathrm{C}$ and a mean annual rainfall around 1750 $\mathrm{mm}$ (Alvares et al. 2013). The mean annual temperature varies between $18.4^{\circ} \mathrm{C}$ in the Evergreen forest region and $17.9^{\circ} \mathrm{C}$ in the Seasonal forest region while the rainfall in these regions may achieve an annual mean of $1660 \mathrm{~mm}$ and $1850 \mathrm{~mm}$, respectively (Alvares et al. 2013). 
The studied sandstone outcrops belong to the Botucatu Formation of the Paraná Sedimentary Basin, originated in the Mesozoic era and presently extending mainly in south-central Brazil (Bigarella \& Salamuni 1961, Kaul 1990). Both the Evergreen and the Seasonal forests occur mostly on the slopes of the Serra Geral Mountain Range, but differing by their predominant exposition.

Besides the Atlantic Evergreen Forest and the Seasonal Forest, regional vegetation also includes the third major physiognomy of Atlantic Forest phytogeographic domain (IBGE 2012), the Araucaria forest, not included in this study.

\section{Sampling method}

It was selected 24 sample units, which consisted of cliffs isolated with a particular exposure. All sampled cliffs are composed of sandstone and have an essentially vertical slope. Among the 24 cliffs, 12 were immersed in the Evergreen Coastal Forest region and 12 were immersed in the semideciduous Seasonal Forest region (Figure 1). Data collection was performed two to three times, in each sample unit, considering different seasons and the flowering period of some species whose identification needed to be confirmed.

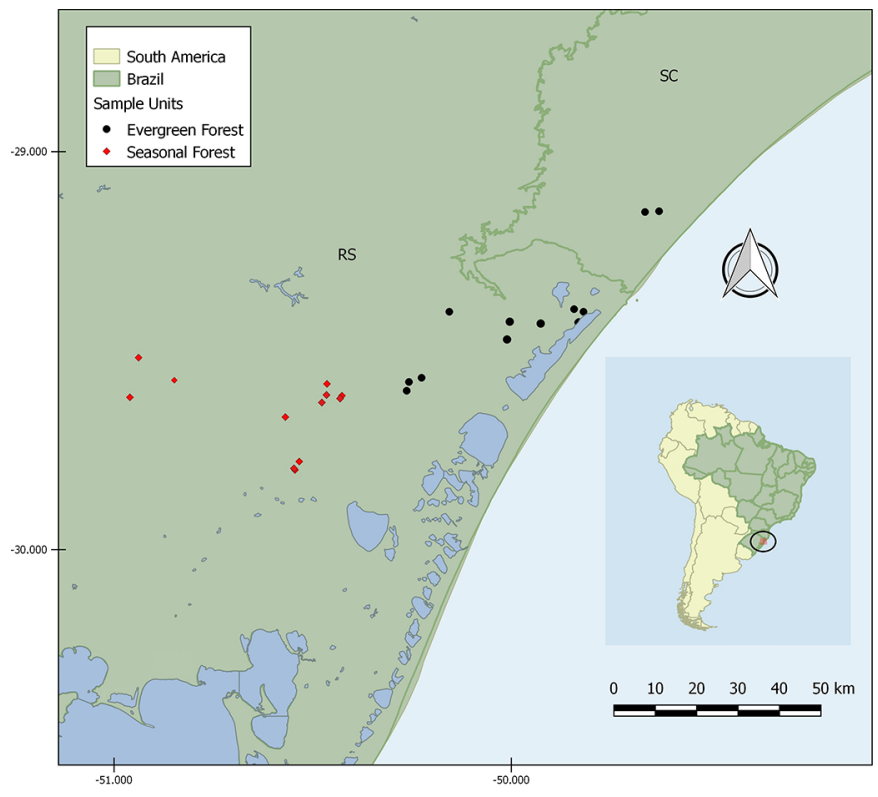

Figure 1. Study area and sampled sites. Black circles represent the cliffs immersed in Evergreen forest region and red squares those immersed in Seasonal forest region. $\mathrm{RS}=$ Rio Grande do Sul state; $\mathrm{SC}=$ Santa Catarina state.

Sampled cliffs in each forest region summed roughly the same area, $19,713 \mathrm{~m}^{2}$ in Evergreen forests and $19,277 \mathrm{~m}^{2}$ in Seasonal forest. We obtained solar radiation and the climatic variables for each site from the WorldClim Global Climate with a spatial resolution equivalent to 30 " ( $\sim \mathrm{km})$ : The bioclimatic variables selected represent annual trends (mean annual temperature, annual precipitation) and seasonality (temperature seasonality, annual temperature range, precipitation seasonality) (Hijmans et al. 2005). Additionally, continentality was obtained from the Envirem data set and is measured by the difference between the average temperature of the warmest month and the average temperature of the coldest month (Title \& Bemmels 2018).
All species of bromeliads on cliffs were sampled, most of them are lithophyte plants, that is, arranged directly on rock or concavities. Some species also used cracks and small terraces on the rock, where a shallow substrate could to exist. Many species were grouped forming what the authors call Bromeliaceae mats. Only Tillandsia usneoides were using other herbaceous plants as support. Bromeliads species growing on the escarpments were registered employing of direct observations and with the aid of high-resolution binoculars, collected through climbing or pruning tools. Fertile specimens were collected and incorporated into the ICN Herbarium in the Federal University of Rio Grande do Sul.

\section{Data analysis}

We measured the spatial variation in species composition using beta diversity with its two components, turnover and nestedness, according to the methodology described by Baselga (2010). The first phenomena is related to species replacement by new species, caused by spatial or environmental constraints, for example (Qian et al. 2005); the last involves species loss in a community or along a gradient, when species found in one site represent a subset of another site, due to non-random processes, caused by circumstances that promote an orderly disaggregation of the assembly (Ulrich \& Gotelli 2007, Baselga 2010).

For each forest type region, we calculated the Sørensen dissimilarity index $(\beta S O R)$ and partitioned it into its turnover, i.e., Simpson dissimilarity index ( $\beta$ SIM) and nestedness ( $\beta$ SNE) components. Nestedness is defined as the difference between $\beta$ SOR and $\beta$ SIM. The estimations were performed with the package "Betapart" in $\mathrm{R}$ (R Development Core Team 2011, Baselga \& Orme 2012). Despite being two antithetic phenomena, turnover and nestedness can occur simultaneously in communities, i.e., they are not mutually excluding (Baselga 2010).

We used PERMANOVA - Permutational Multivariate Analysis of Variance (Anderson 2001), to test the individual relationships between each of the environmental predictor matrices and the beta diversity metrics ( $\beta$ SOR, $\beta$ SIM, and $\beta$ SNE), in each study region. Beside the continentality and solar radiation, we had chosen the variables representing the climatic variation in the forest and seasonal transition zone: mean annual temperature, annual precipitation, temperature seasonality, annual temperature range, and precipitation seasonality. Thus, we analyzed whether areas with more dissimilar species compositions were associated with increasing environmental distances. These relationships were examined based on the partial $\mathrm{R}^{2}$, and the significance was estimated using 999 permutations, in the R package "Vegan" (Oksanen et al. 2013).

The relative contributions of environmental and spatial factors in the structuring of communities were analysed by partitioning the variation from distance-based redundancy analysis (db-RDA) and variation partitioning based on the adjusted $\mathrm{R}^{2}$ (Borcard et al. 1992, Legendre \& Legendre 1998, Legendre \& Andersson 1999, Smith \& Lundholm 2010) Although there are critical issues in using statistical methods for variation partitioning, the approaches that divide environmental and spatial controls into community composition are recognized as important for ecological studies (Gilbert \& Bennett 2010). 
Initially, separate analyses were run for the set of spatial and environmental variables. The distance matrix of total beta diversity ( $\beta \mathrm{SOR})$ was used as the response variable. The environmental predictor matrix comprised bioclimatic variables, continentality and solar radiation, standardized through logarithmic transformations to homogenize the data distribution. A forward-selection procedure was applied to environmental dataset. The RDA with the selected variables (Temperature Seasonality - TS, Annual Temperature Range - TR, Solar radiation - SR) served as the model for the analysis of variance partitioning. We also test the multicollinearity in select variables to be used in the analyse (Borcard et al. 1992).

The spatial matrix (geographic overland distances) was obtained through of distance-based Moran's Eigenvector Maps (dbMEM, formerly called principal coordinates of neighbour matrices, PCNM). These filters are generated from a truncated Euclidean distance matrix between sample units based on their geographical coordinates and can be used as explanatory variables to model spatial relationships in community data (Dray et al. 2006, 2012). This procedure generated a total of 18 MEM filters, each of which corresponds to a specific spatial structure and scale: the first MEM variables model broader-scale patterns, whereas the subsequent variables progressively represent finer-scale patterns (Borcard et al. 2004). A forward-selection procedure was applied to spatial dataset. Only the significant spatial filters were retained for variation partitioning (MEM1, MEM2, MEM3, MEM 4, MEM16, MEM17, MEM18), corresponding to the first four and last three spatial predictors.

To perform variation partitioning, the three data matrix was required: Beta diversity matrix, environmental variables, spatial variables (Moran's Eigenvector Maps - MEM) (Dray et al. 2006). Thereafter, the variation in the matrix of the community was decomposed into components of explanation: purely environmental, both spatial and environmental, purely spatial and residual or unexplained (Borcard et al. 1992). The analysis was performed from three sets of multivariate linear regressions with the beta diversity matrix as the response. These regressions estimate the amount of variation explained by environmental and spatial predictors, alone and in combination (Peres-Neto et al. 2006). The significance of the environmental and spatial models generated by the dbRDAs was tested with a permutation test for constrained correspondence analysis.

The distance-based Moran's Eigenvector Maps were performed with the "adespatial" package (Dray et al. 2018). The RDA analysis, variation partitioning and Moran spectral randomization was executed with the "vegan", "adespatial", and "spdep" packages (Oksanen et al. 2013, Bivand \& Wong 2018, Dray et al. 2018), all in the statistical program R (R Development Core Team 2011).

\section{Results}

We sampled a total of 26 bromeliad species, belonging to nine genera (Aechmea, Bromelia, Billbergia, Dyckia, Edmundoa, Nidularium, Tillandsia, Vriesea, and Wittrockia) and three subfamilies (Bromelioideae, Tillandsioideae, and Pitcairnoideae) (Table 1). The number of species per cliff ranged from one to 11 in Evergreen forest and from one to seven for Seasonal Forest. The total richness in each region was 23 species in Evergreen forest and 13 species in Seasonal Forest, and 10 species were shared between the two environments.
In assessing the proportion of each component of beta diversity, we observed a significantly higher contribution of turnover to nestedness, both when considering all the study area and those cliffs sampled in each forest type, with values ranging from 0.766 to 0.876 (pairwise $\beta$ SIM). Total beta diversity (pairwise $\beta \mathrm{SOR}$ ) was 0.851 for Evergreen forest, 0.900 for Seasonal forest and 0.925 for both forest types (Table 2).

Solar radiation was one of the factors that most influenced Bromeliaceae beta diversity, considering forest physiognomies separately and in an integrated manner. In Evergreen forest, the Annual Temperature Range (TR) also contributes to the variation in species composition, taking into account $\beta$ SIM and $\beta$ SOR. Beside this variable, Precipitation Seasonality (PS) also explained the total beta diversity ( $\beta S O R$ ) in this forest type. In Seasonal forest, both $\beta$ SIM and $\beta S O R$ were influenced by the Mean Annual Temperature (AT), Temperatura Seasonality (TS), Temperature Annual Range (TR) and Continentality (CO). Considering both forest types, only Annual Precipitation (AP) and Continentality (CO) did not influence beta diversity of epilithic bromeliad communities. In general, the models revealed that the strongest environmental effects were on total beta diversity ( $\beta S O R$ ), followed by the turnover component of beta diversity ( $\beta$ SIM) (Table 3).

The relationship between all sampled cliffs and the total set of selected spatial and environmental variables is represented in two dbRDA plots (Figure 2 and Figure 3). The permutation tests for these analyses were significant for spatial variables, for environmental variables and environmental variations spatially structured. However, if isolated, environmental predictors fail to explain the variation of the data. Essentially, our results showed that the distribution of rock-dwelling Bromeliaceae is limited both by spatial distances and by environmental variables acting within these limits. In variation partitioning, the spatial and environmental variables explained $62.0 \%$ of the variation found in the structure of the bromeliad communities.

The purely spatial component explained $26.5 \%$, while the environmental fraction alone accounted for $3.40 \%$ of the variation. The percentage of the shared variation between spatial and environmental variables was $32.1 \%$. However, $38.0 \%$ of the variation in beta diversity could not be explained by either of these variables (Table 4).

\section{Discussion}

This research provides ecological information on the Bromeliaceae inhabiting rocky cliffs in southern Brazil. Our results showed how the composition of bromeliads growing on this substrate varies at the boundary between evergreen and seasonal forest types, and how spatial and environmental factors influence the structuring of these communities. Beta diversity is arranged by spatial turnover reflecting climatic differences between sites. Thus, bromeliad composition is determined by both deterministic environmental factors and stochastic spatial effects.

The total beta diversity patterns showed a much stronger contribution of species turnover than species nestedness. This result was expected, considering that species turnover reveals the variation in community structure from one sampling unit to another along a spatial, temporal or environmental gradient (Anderson et al. 2011). The replacement of species along space is related to environmental difference throughout the study area, which comprises several climatic and landscape regimes, affecting the structure in forest communities of the Southern Brazilian Atlantic Forest (Oliveira-Filho \& Fontes 2000, Bergamin et al. 2012). Contrary to nestedness, spatial turnover indicates the replacement of some species 
Beta diversity of Bromeliaceae on rock cliffs

Table 1. Bromeliad species sampled on sandstone cliffs in the South Brazilian Atlantic Forest, and their frequence in Evergreen (E) and Seasonal (S) forest types.

\begin{tabular}{|c|c|c|c|c|}
\hline \multirow[b]{2}{*}{ Subfamilies } & \multirow[b]{2}{*}{ Species } & \multirow[b]{2}{*}{ Author } & \multicolumn{2}{|c|}{ Forest Type } \\
\hline & & & $\mathrm{E}$ & $\mathrm{S}$ \\
\hline \multirow[t]{7}{*}{ Bromelioideae } & Aechmea comata & (Gaudich.) Baker & 2 & 5 \\
\hline & Aechmea nudicaulis & (L.) Griseb. & 1 & 0 \\
\hline & Aechmea recurvata & (Klotzsch) L.B. Sm. & 0 & 1 \\
\hline & Bromelia antiacantha & Bertol. & 3 & 1 \\
\hline & Edmundoa lindenii & (Regel) Leme & 2 & 0 \\
\hline & Nidularium innocentii & Lem. & 1 & 0 \\
\hline & Wittrockia superba & Lindm. & 6 & 0 \\
\hline \multirow{9}{*}{ Tillandsiodeae } & Tillandsia geminiflora & Brongn. & 1 & 1 \\
\hline & Tillandsia mallemontii & Glaz. ex Mez & 1 & 0 \\
\hline & Tillandsia polzii & Ehlers & 2 & 5 \\
\hline & Tillandsia recurvata & (L.) L. & 3 & 1 \\
\hline & Tillandsia stricta & Sol. & 1 & 0 \\
\hline & Tillandsia usneoides & (L.) L. & 8 & 2 \\
\hline & Tillandsia xiphioides & Ker Gawl. & 2 & 0 \\
\hline & Vriesea carinata & Wawra & 1 & 0 \\
\hline & Vriesea friburgensis & Mez & 0 & 2 \\
\hline
\end{tabular}

Table 2. Total beta diversity, i.e., Sørensen dissimilarity ( $\beta S O R$ ) and its two components, turnover (Simpson dissimilarity, $\beta$ SIM) and nestedness $(\beta S N E)$ in Evergreen Forest, Seasonal Forest and Both Forest Types.

\begin{tabular}{cccc}
\hline Forest types & $\beta S O R$ & $\beta S I M$ & $\beta S N E$ \\
\hline Evergreen Forest & 0.851 & 0.766 & 0.084 \\
Seasonal Forest & 0.900 & 0.847 & 0.053 \\
Both Forests & 0.925 & 0.876 & 0.049 \\
\hline
\end{tabular}

by others, as a consequence of environmental arrangements or spatial and historical restrictions (Qian et al. 2005).

The similarity between species matrices was positively correlated with the similarity of local ecological conditions, evidencing the influence of environmental factors on the composition of Bromeliaceae growing on cliffs, particularly the $\beta$ SIM diversity component. The degree of beta diversity for the two forest types found in our study is surprising because it is a transitional area, but corroborates with other studies applied to different forest components of the Atlantic Forest (Bergamin et al. 2012, Menini Neto et al. 2016). In addition, the changes in physiognomy are generally associated with higher values of $\beta$ diversity (Pérez-García et al. 2009). The high turnover rates of species in each forest type also support other studies and reinforce the need to expand conservation areas of rocky habitats within each of these types (Bergamin et al. 2017).

Solar radiation was important variable in species' shifts in Evergreen forest, in Seasonal forest, and especially when considering the entire studied area. Variation in species diversity and composition on inselbergs in southern Brazil had already been associated with different exposures to solar radiation (Ferreira et al. 2014, Carlucci et al. 2015). The physiological sensitivity and performance of bromeliads are directly related to their thermal tolerances (Benzing 2000), which also corroborates the importance of this variable. Recently, studies have shown differences in the anatomy and morphology of epilithic species, reinforcing the existence of different adaptations in certain species to deal with drought in rocky environments (Hunter 2016, de Paula et al. 2019). Many bromeliads are adapted to environmental conditions with low water availability, being favoured by several functional attributes capable of efficiently capturing water and minimizing its loss. The CAM photosynthesis also 
Table 3. Explained variation $\left(\mathrm{R}^{2}\right)$ of distance matrices representing effects of Solar Radiation (SR), Annual Mean Temperature (AT), Temperature Seasonality (TS), Annual Temperature Range (TR), Annual Precipitation (AP), Precipitation Seasonality (PS), and Continentality (CO) on total beta diversity (Sørensen dissimilarity, $\beta$ SOR) and its turnover (Simpson dissimilarity, $\beta$ SIM) and nestedness ( $\beta$ SNE) components of bromeliads on cliffs immersed in Evergreen Forest, Seasonal Forest and Both Forest Types.

\begin{tabular}{|c|c|c|c|c|c|c|c|c|c|}
\hline & \multicolumn{3}{|c|}{ Evergreen Forest } & \multicolumn{3}{|c|}{ Seasonal Forest } & \multicolumn{3}{|c|}{ Both Forest Types } \\
\hline & $\beta S O R$ & $\beta$ SIM & $\beta \mathrm{SNE}$ & $\beta S O R$ & $\beta$ SIM & $\beta \mathrm{SNE}$ & $\beta S O R$ & $\beta$ SIM & $\beta \mathrm{SNE}$ \\
\hline SR & $0.211 * *$ & $0.299 *$ & - & $0.153 *$ & $0.150 *$ & - & $0.238 * *$ & $0.292 * *$ & - \\
\hline TS & - & - & - & $0.207^{*}$ & $0.185^{*}$ & - & $0.065^{*}$ & $0.072 *$ & - \\
\hline TR & $0.152 *$ & $0.226^{*}$ & - & - & - & - & $0.057 *$ & $0.074 *$ & - \\
\hline PS & $0.029 *$ & - & - & - & - & - & $0.101 * *$ & $0.002 * *$ & - \\
\hline $\mathrm{CO}$ & - & - & & $0.099 *$ & $0.120 *$ & - & - & - & - \\
\hline
\end{tabular}

Signif. codes: * P-value $<0.05 ; * *$ P-value $<0.01$.

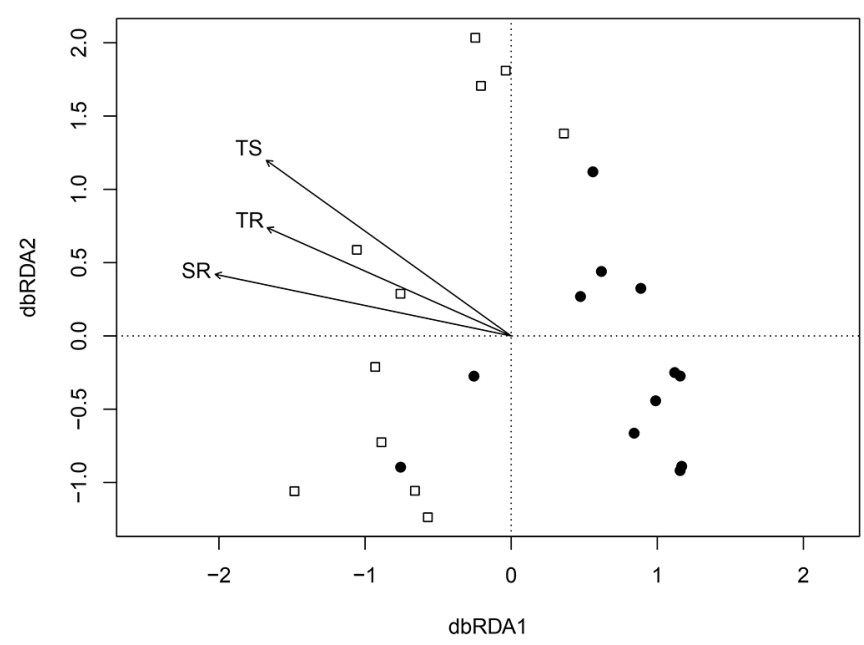

Figure 2. Distance-based Redundancy Analysis (dbRDA) of species assemblages and environmental variables in sandstone cliffs. (dbRDA, axis $1=24 \%$, axis 2 $=13 \%$ ). Temperature Seasonality (AT), Annual Temperature Range (TR), and Solar Radiation (SR). White squares correspond to cliffs in Seasonal Forest and black circles correspond to cliffs in Evergreen Forest.

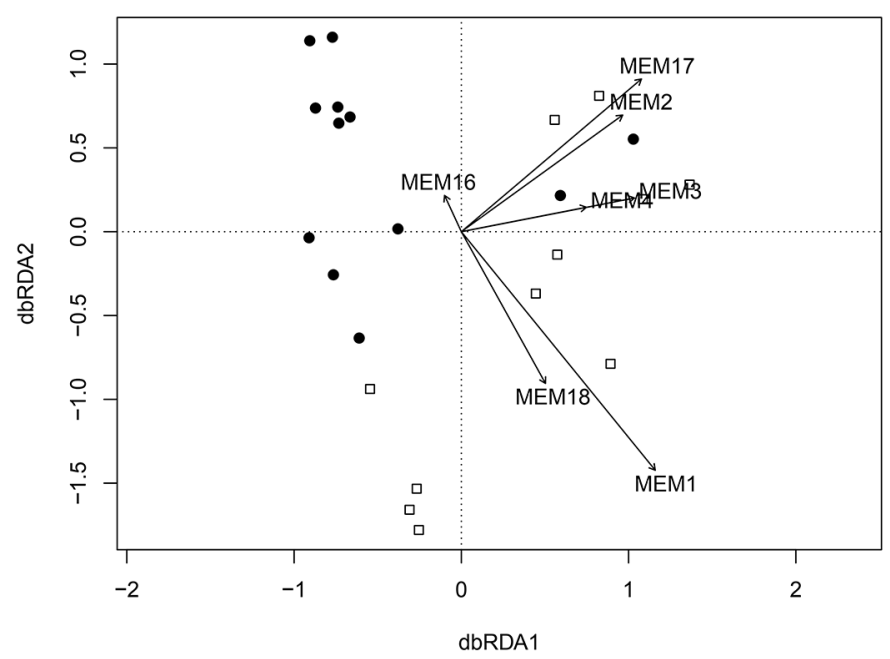

Figure 3. Distance-based Redundancy Analysis (dbRDA) of species assemblages and spatial variables in sandstone cliffs. (dbRDA, axis $1=31 \%$, axis $2=18 \%$ ). Selected spatial descriptors (forward selection): MEM 1, MEM 2, MEM 3, MEM 4, MEM 16, MEM 17, MEM 18. White squares correspond to cliffs in Seasonal forest and black circles correspond to cliffs in Evergreen Forest.

Table 4. Results of the partial dbRDA analysis (variation partitioning) for the composition of epilithic bromeliads growing on sandstone cliffs immersed in Atlantic Forest matrix.

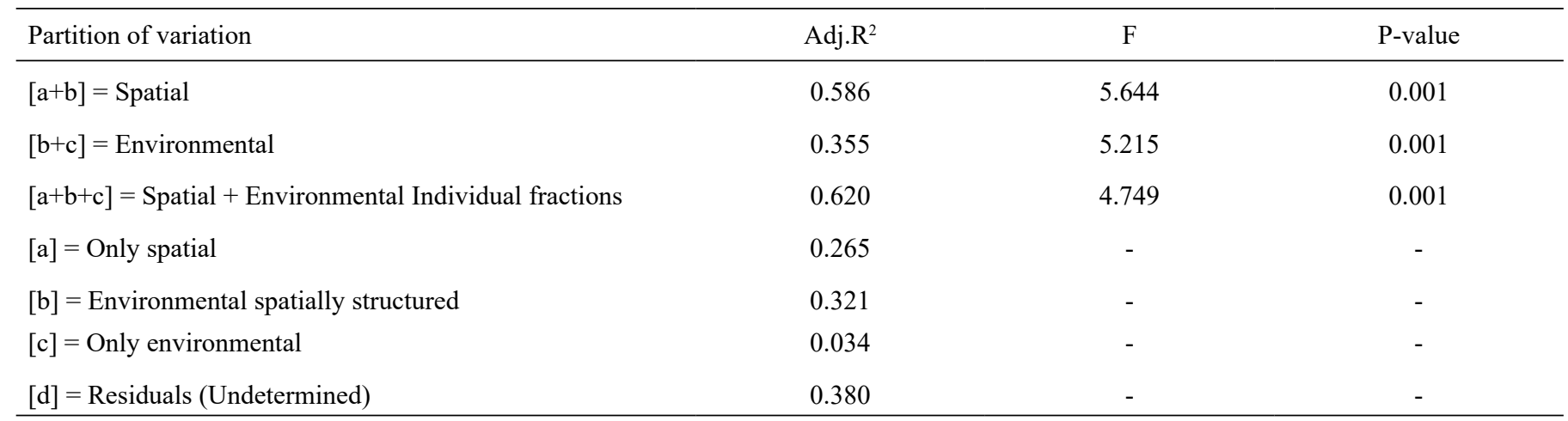


is significantly associated with increased diversification in Bromeliaceae in these habitats (Martin 1994, Reinert 1998, Quezada \& Gianoli 2011). These adaptations are also effective in moist forests, for those bromeliad species growing on intermittently dry habitats, as rocky outcrops and the upper canopy of rainforests (Benzing 2000).

Temperature seasonality, annual range temperature and annual temperature influence the beta diversity patterns of rock-dwelling bromeliads, especially in seasonal forests and in the transition zone between the two forest types. This is probably because the coastal to inland climatic and topographic gradients affect several species even in areas with the same forest physiognomy, which is evidenced by lower temperatures, especially in winter, towards the Serra Geral Mountain Range (Alvares et al. 2013). Moreover, the richness of bromeliads in coastal Brazil shows strong latitudinal variations, that reflects a temperature gradient, decreasing both towards northern and southern from a central hotspot around Rio de Janeiro and São Paulo states (Martinelli et al. 2008).

Considering the studied region as a transition between two different forest types, differences in precipitation are less evident. However, seasonality precipitation was an important factor conditioning the turnover component of total beta diversity ( $\beta \mathrm{SOR}$ ) of the bromeliad communities. Analogous results were found for the tree component, being the differentiation between Ombrophilous (Evergreen) and Semideciduous (Seasonal) forests strongly correlated with rainfall regime and temperature variation (Oliveira-Filho \& Fontes 2000). A similar situation has been recorded in studies performed on South American and African inselbergs, showing rainfall as the driver of floristic heterogeneity at regional scale (Parmentier et al. 2005, Sarthou et al. 2017).

Continentality was an important variable for species composition in seasonal forests, expressed by large proportions of variation explained in total beta diversity. Corroborating this assumption, the pattern of geographical distribution of bromeliads in Rio Grande do Sul and Santa Catarina has great longitudinal influence, mainly due to the effect of the Serra Geral Highlands (South Brazilian Plateau) and to the species irradiation of the more tropical Atlantic Forest into the southern of this mountains (Winkler 1982, Reitz 1983, Waechter 2007). Furthermore, the distance from the ocean, used as proxy for continentality, is considered an important variable in the composition of epiphytic bromeliads in South Brazilian Atlantic Forest (Fontoura et al. 2012).

Several supra-generic systematic groups of bromeliads are associated with different biogeographic regions or particular environmental conditions, thus promoting the replacement of species according to environmental characteristics (Benzing 2000, Givnish et al. 2011). In view of that environmental variables affected the floristic similarity of the communities, we can infer that vegetation is not exclusively influenced by local edaphic and hydrological factors, although these may also influence local vegetation (Hobohm 2014). In addition to having a clear relationship between climatic variables and species distribution, there is a sharing of species between the vegetation matrix and the rocky environment (Melo \& Waechter 2018).

The detected variation in the structure of bromeliad communities is a result of spatial variables, as well as environmental variables structured along to the geographic space, which in fact had a major proportion in the explanation of data variation. A spatially structured gradient was also found in studies conducted in rocky outcrop in French Guiana and in south-eastern rock grasslands Brazil (Silva Mota et al. 2018, Sarthou et al. 2017). Similarly, floristic patterns of Bromeliaceae epiphytes in the Brazilian Atlantic Forest were mainly associated with space (Leitman et al. 2015). This result may also be related to the dispersion capacity of some species of bromeliads, or suggest the absence of some pollinators (bats, hummingbirds, bees and butterflies), indicating that environmental constrains positively correlate with spatial distances affect the floristic differences in this spatial scale (Brown \& Lomolino 2001). Additionally, spatial distance has been used by researchers as a proxy for dispersion limitation (Zellweger et al. 2017). The percentage of variation in beta diversity that cannot be explained by either space or the environment predictors may be related to local environmental variations, biological interactions, and mainly to the degree of disturbance in the areas surrounding the cliffs, which were not measured.

In fact, neutral and niche processes can operate together to define the patterns of species diversity and distribution (Leibold \& McPeek 2006, Segre et al. 2014), and our results clearly corroborate this premise, indicating that both are important in the structuring of epilithic bromeliad communities and the maintenance of local and regional biodiversity. Spatial filters and spatially structured environmental variations assume that species dissimilarity increases with increasing distance due to the relation between niche processes and environmental gradients (Bell et al. 2006). The high turnover values indicate that species occupy different spaces, and that the sites differ in environmental characteristics, selecting bromeliad species. In order to conserve this diversity of species, it is important to maintain the present environmental characteristics and identify habitats where species are restricted. In addition, if beta diversity is the result of spatial and environmental processes, the conservation of landscape organization and species-space-environment relationships is highly necessary to maintain species diversity.

\section{Acknowledgements}

We thank Tito Stumpf, Fernando da Luz and Gessica Radtke for their assistance in the field work. We are also grateful to Gerhard Overbeck, Guilherme Seger, and Juliano Oliveira for the useful comments on the manuscript. The first author was supported by CAPES with a $\mathrm{PhD}$ scholarship.

\section{Authors' Contributions}

Edilaine Andrade Melo: Substantial contribution in the concept and design of the study; contribution to data collection; contribution to data analysis and interpretation, contribution to manuscript preparation and Contribution to critical revision, adding intellectual content.

Jorge Luiz Waechter: Substantial contribution in the concept and design of the study; contribution to data collection; contribution to data analysis and interpretation, contribution to manuscript preparation and Contribution to critical revision, adding intellectual content.

\section{Conflicts of interest}

The authors declare that they have no conflict of interest related to the publication of this manuscript.

\section{Ethics}

This study did not involve humans and /or clinical trials, following all applicable guidelines. 


\section{References}

ALVARES, C.A., STAPE, J.L., SENTELHAS, P.C., DE MORAES GONÇALVES, J.L. \& SPAROVEK, G. 2013. Koppen's climate classification map for Brazil. Meteorol. Zeitschrift 22(6):711-728.

ANDERSON, M.J. 2001. A new method for non-parametric multivariate analysis of variance. Austral Ecol. 26(2001):32-46.

ANDERSON, M.J., CRIST, T.O., CHASE, J.M., VELLEND, M., INOUYE, B.D., FREESTONE, A.L., SANDERS, N.J., CORNELL, H. V., COMITA, L.S., DAVIES, K.F., HARRISON, S.P., KRAFT, N.J.B., STEGEN, J.C. \& SWENSON, N.G. 2011. Navigating the multiple meanings of $\beta$ diversity: A roadmap for the practicing ecologist. Ecol. Lett. 14(1):19-28.

BASELGA, A. 2010. Partitioning the turnover and nestedness components of beta diversity. Glob. Ecol. Biogeogr. 19(1):134-143.

BASELGA, A. \& ORME, C.D.L. 2012. Betapart: An R package for the study of beta diversity. Methods Ecol. Evol. 3(5):808-812.

BELL, G., LECHOWICZ, M.J. \& WATERWAY, M.J. 2006. The comparative evidence relating to functional and neutral interpretations of biological communities. Ecology 87(6):1378-1386.

BENZING, D.H. 2000. Bromeliaceae: Profile of an Adaptive Radiation. Publ. by Press Synd. Univ. cambridge 59(2):325-334.

BERGAMIN, R.S., BASTAZINI, V.A.G., VÉLEZ-MARTIN, E., DEBASTIANI, V., ZANINI, K.J., LOYOLA, R. \& MÜLLER, S.C. 2017. Linking beta diversity patterns to protected areas: lessons from the Brazilian Atlantic Rainforest. Biodivers. Conserv. (7):1557-1568.

BERGAMIN, R.S., MÜLLER, S. \& MELLO, R.S.P. 2012. Indicator species and floristic patterns in different forest formations in southern Atlantic rainforests of Brazil. Community Ecol. 13(2):162-170.

BIGARELLA, J.J. \& SALAMUNI, R. 1961. Early Mesozoic wind patterns as suggested by dune bedding in the botucatu sandstone of Brazil and Uruguay. Geol. Soc. Am. Bull. (72):1089-1106.

BIVAND, R.S. \& WONG, D.W.S. 2018. Comparing implementations of global and local indicators of spatial association. Test 27(3):716-748.

BORCARD, D., LEGENDRE, P., AVOIS-JACQUET, C. \& TUOMISTO, H. 2004. Dissecting the spatial structure of ecological data at multiple scales. Ecology 85(7):1826-1832.

BORCARD, D., LEGENDRE, P. \& DRAPEAU, P. 1992. Partialling out the spatial component of ecological variation. Ecology 73(3):1045-1055.

BROWN, J.H. \& LOMOLINO, M. V. 2001. Concluding remarks: historical perspective and the future of island biogeography theory. Glob. Ecol. Biogeogr. 9(1):87-92.

CARLUCCI, M.B., BASTAZINI, V.A.G., HOFMANN, G.S., DE MACEDO, J.H., IOB, G., DUARTE, L.D.S., HARTZ, S.M. \& MÜLLER, S.C. 2015. Taxonomic and functional diversity of woody plant communities on opposing slopes of inselbergs in southern Brazil. Plant Ecol. Divers. 8(2):187-197.

DO CARMO, F.F., DE CAMPOS, I.C. \& JACOBI, C.M. 2016. Effects of finescale surface heterogeneity on rock outcrop plant community structure. J. Veg. Sci. 27(1):50-59.

COTTENIE, K. 2005. Integrating environmental and spatial processes in ecological community dynamics. Ecol. Lett. 8(11):1175-1182.

DRAY, S., BAUMAN, D., BLANCHET, G., BORCARD, D., CLAPPE, S., GUENARD, G., JOMBART, T., LAROCQUE, G., LEGENDRE, P., MADI, N. \& WAGNER, H.H. 2018. adespatial: Multivariate Multiscale Spatial Analysis. http://CRAN.R-project.org/package=adespatial.

DRAY, S., LEGENDRE, P. \& PERES-NETO, P.R. 2006. Spatial modelling: a comprehensive framework for principal coordinate analysis of neighbour matrices (PCNM). Ecol. Modell. 196(3-4):483-493.

DRAY, S., PÉLISSIER, R., COUTERON, P., FORTIN, M.J., LEGENDRE, P., PERESNETO, P.R., BELLIER, E., BIVAND, R., BLANCHET, F.G., DE CÁCERES, M., DUFOUR, A.B., HEEGAARD, E., JOMBART, T., MUNOZ, F., OKSANEN, J., THIOULOUSE, J. \& WAGNER, H.H. 2012. Community ecology in the age of multivariate multiscale spatial analysis. Ecol. Monogr. 82(3):257-275.
DUARTE, L.D.S., HOFMANN, G.S., DOS SANTOS, M.M.G., HARTZ, S.M. \& PILLAR, V.D. 2010. Testing for the influence of niche and neutral factors on sapling community assembly beneath isolated woody plants in grasslands. J. Veg. Sci. 21(3):462-471.

FERREIRA, G.E., MARCHI, T. De \& LAROCCA, J. 2014. Flora vascular e distribuição de espécies por micro-habitat em um morro testemunho no Sul do Brasil. Pesqui. Botânica 54129-147.

FONTOURA, T., SCUDELLER, V.V. \& COSTA, A.F. da. 2012. Floristics and environmental factors determining the geographic distribution of epiphytic bromeliads in the Brazilian Atlantic Rain Forest. Flora Morphol. Distrib. Funct. Ecol. Plants 207(9):662-672.

GASTON, K.J. \& CHOWN, S.L. 2005. Neutrality and the niche. Funct. Ecol. 19(1):1-6.

GILBERT, B. \& BENNETT, J.R. 2010. Partitioning variation in ecological communities: do the numbers add up? J. Appl. Ecol. 47(5):1071-1082.

GIVNISH, T.J., BARFUSS, M.H.J., VAN EE, B., RIINA, R., SCHULTE, K., HORRES, R., GONSISKA, P.A., JABAILY, R.S., CRAYN, D.M., SMITH, J.A.C., WINTER, K., BROWN, G.K., EVANS, T.M., HOLST, B.K., LUTHER, H., TILL, W., ZIZKA, G., BERRY, P.E. \& SYTSMA, K.J. 2011. Phylogeny, adaptive radiation, and historical biogeography in Bromeliaceae: Insights from an eight-locus plastid phylogeny. Am. J. Bot. 98(5):872-895.

GRINNELL, J. 1917. The niche-relationships of the California Trasher. Auk 34(4):427-433.

HIJMANS, R.J., CAMERON, S.E., PARRA, J.L., JONES, P.G. \& JARVIS, A. 2005. The WorldClim interpolated global terrestrial climate surfaces. http:// www.worldclim.org.

HOBOHM, C. 2014. Endemism in vascular plants. Springer, Flensburg.

HUBBELL, S. 2001. The Unified Neutral Theory of Biodiversity and Biogeography. Princeton University Press, Princeton.

HUNTER, J.T. 2016. Differences in Functional Trait Distribution between Inselberg and Adjacent Matrix Floras. Int. J. Ecol. 1-7.

IBGE. 2012. Manual Técnico da Vegetação Brasileira. 2 ed. Instituto Brasileiro de Geografia e Estatística, Rio de Janeiro.

KAUL, P.F.. 1990. Geologia. In Geografia do Brasil: Região Sul IBGE, Rio de Janeiro, p.29-54.

LARSON, D.W., MATTHES, U. \& KELLY, P.E. 2000. Cliff Ecology: Pattern and Process in Cliff Ecosystems. Cambridge University Press, Cambridge.

LEÃO, T.C.C., FONSECA, C.R., PERES, C. a. \& TABARELLI, M. 2014. Predicting extinction risk of brazilian atlantic forest angiosperms. Conserv. Biol. 28(5):1349-1359.

LEGENDRE, P. \& ANDERSSON, M.J. 1999. Distance-based redundancy analysis: Testing multispecies responses in multifactorial ecological experiments. Ecol. Monogr. 69(1):1-24.

LEGENDRE, P. \& LEGENDRE, L. 1998. Numerical Ecology - Second English Edition. Elsevier Science, Amsterdam.

LEIBOLD, M.A. \& MCPEEK, M.A. 2006. Coexistence of the niche and neutral perspectives in community ecology. Ecology 87(6):1399-1410.

LEITMAN, P., AMORIM, A.M., SANSEVERO, J.B.B. \& FORZZA, R.C. 2015. Floristic patterns of epiphytes in the Brazilian Atlantic Forest, a biodiversity hotspot. Bot. J. Linn. Soc. 179(4):587-601.

MACHADO, T.M., FORZZA, R.C. \& STEHMANN, J.R. 2016. Bromeliaceae from caparaó national park, minas gerais/espírito Santo States, Brazil, with notes on distribution and conservation. Oecologia Aust. 20(2):133-146.

MARTIN, C.E. 1994. Physiological Ecology of the Bromeliaceae. Bot. Rev. 60(1):1-82.

MARTINELLI, G., VIEIRA, C., GONZALEZ, M., LEITMAN, P.M., PIRATININGA, A., COSTA, A.F. \& FORZZA, R.C. 2008. Bromeliaceae da Mata Atlântica brasileira: lista de espécies, distribuição e conservação. Rodriguésia 59(1):209-258.

MELO, E.A. \& WAECHTER, J.L. 2018. Effect of vegetation matrix on diversity and distribution of epipetric bromeliads in a transitional region between Evergreen and Seasonal Forest. Flora 249(1):77-85. 
MENININETO, L., FURTADO, S.G., ZAPPI, D.C., DE OLIVEIRAFILHO,A.T. \& FORZZA, R.C. 2016. Biogeography of epiphytic Angiosperms in the Brazilian Atlantic forest, a world biodiversity hotspot. Rev. Bras. Bot. 39(1):261-273.

MITTERMEIER, R.A., VAN DIJK, P.P., RHODIN, A.G.J. \& NASH, S.D. 2015. Hotspots revisited: Earth's biologically richest and most endangered ecoregions. Chelonian Conserv. Biol. 14(1):2-10.

OKSANEN, J., BLANCHET, F.G., KINDT, R., LEGENDRE, P., MINCHIN, P.R., O'HARA, R.B., SIMPSON, G.L., SOLYMOS, P., STEVENS, M.H.H. \& WAGNER, H. 2013. Package 'vegan.' R Packag. ver. 2.0-8 254.

OLIVEIRA-FILHO, A. \& FONTES, M. 2000. Patterns of Floristic Differentiation among Atlantic Forests in Southeastern Brazil and the Influence of Climate. Biotropica 32(2):793-810.

PARMENTIER, I., STÉVART, T. \& HARDY, O.J. 2005. The inselberg flora of Atlantic Central Africa. I. Determinants of species assemblages. J. Biogeogr. 32(4):685-696

DE PAULA, L.F.A., FORZZA, R.C., NERI, A. V., BUENO, M.L. \& POREMBSKI, S. 2016. Sugar Loaf Land in south-eastern Brazil: a centre of diversity for mat-forming bromeliads on inselbergs. Bot. J. Linn. Soc. 181(3):459-476.

DE PAULA, L.F.A., KOLB, R.M., POREMBSKI, S., SILVEIRA, F.A.O. \& ROSSATTO, D.R. 2019. Rocks and leaves: Can anatomical leaf traits reflect environmental heterogeneity in inselberg vegetation? Flora Morphol. Distrib. Funct. Ecol. Plants 91-98.

PERES-NETO, P.R., LEGENDRE, P., DRAY, S. \& BORCARD, D. 2006. Variation partitioning of species data matrices: estimation and comparison of fractions. Ecology 87(10):2614-1625.

PÉREZ-GARCÍA, E.A., SEVILHA, A., MEAVE, J.A. \& SCARIOT, A. 2009 Floristic differentiation in limestone outcrops of southern Mexico and central Brazil: a beta diversity approach. Boletín la Soc. Botánica México 58(84):45-58.

POREMBSKI, S. 2005. Floristic diversity of African and South American inselbergs : a comparative analysis. Acta Bot. Gall. Bot. Lett. 152(March 2015):573-580.

POREMBSKI, S. \& BARTHLOTT, W. 2000. Granitic and gneissic outcrops (inselbergs) as centers of diversity for desiccation-tolerant vascular plants. Plant Ecol. 151(1):19-28.

POREMBSKI, S., MARTINELLI, G., OHLEMÜLLER, R. \& BARTHLOTT, W. 1998. Diversity and ecology of saxicolous vegetation mats on inselbergs in the Brazilian Atlantic rainforest. Divers. Distrib. 4(3):107-119.

POREMBSKI, S., SEINE, R. \& BARTHLOTT, W. 1997. Inselberg vegetation and the biodiversity of granite outcrops. J. R. Soc. West. Aust. 80(3):193199.

QIAN, H., RICKLEFS, R.E. \& WHITE, P.S. 2005. Beta diversity of angiosperms in temperate floras of eastern Asia and eastern North America. Ecol. Lett. $8(1): 15-22$.

QUEZADA, I.M. \& GIANOLI, E. 2011. Crassulacean acid metabolism photosynthesis in Bromeliaceae : an evolutionary key innovation. Biol. J. Linn. Soc. (104):480-486.

R DEVELOPMENT CORE TEAM, R. 2011. R: A Language and Environment for Statistical Computing.

REINERT, F. 1998. Epiphytes: Photosynthesis, water balance and nutrients. Oecologia Bras. 87-108.

REITZ, R. 1983. Bromeliáceas e a malária-bromélia endêmica. In Flora ilustrada catarinense (E. REITZ, ed.) Herbário Barbosa Rodrigues, Itajaí, p.808.
RIBEIRO, M.C., METZGER, J.P., MARTENSEN, A.C., PONZONI, F.J. \& HIROTA, M.M. 2009. The Brazilian Atlantic Forest: How much is left, and how is the remaining forest disturbed? Implications for conservation. Biol. Conserv. 142(6):1141-1153.

RICKLEFS, R.E. \& SCHLUTER, D. 1995. Species diversity in ecological communities: historical and geographical perspectives. Madrono 42(4):523-528.

ROCHA, F.S., DUARTE, L. da S. \& WAECHTER, J.L. 2014. Positive association between Bromelia balansae (Bromeliaceae) and tree seedlings on rocky outcrops of Atlantic forest. J. Trop. Ecol. 31(02):195-198.

SARAIVA, D.D., SOUSA, K.D.S. De \& OVERBECK, G.E. 2015. Multiscale partitioning of cactus species diversity in the South Brazilian grasslands: Implications for conservation. J. Nat. Conserv. 24(1):117-122.

SARTHOU, C., PAVOINE, S., GASC, J.P., DE MASSARY, J.C. \& PONGE, J.F. 2017. From inselberg to inselberg: Floristic patterns across scales in French Guiana (South America). Flora Morphol. Distrib. Funct. Ecol. Plants $147-158$.

SCARANO, F.R. 2002. Structure, function and floristic relationships of plant communities in stressful habitats marginal to the Brazilian Atlantic rainforest. Ann. Bot. 90(4):517-524.

SEGRE, H., RON, R., DE MALACH, N., HENKIN, Z., MANDEL, M. \& KADMON, R. 2014. Competitive exclusion, beta diversity, and deterministic vs. stochastic drivers of community assembly. Ecol. Lett. 17(11):1400-1408.

SILVA MOTA, G., LUZ, G.R., MOTA, N.M., SILVA COUTINHO, E., DAS DORES MAGALHÃES VELOSO, M., FERNANDES, G.W. \& NUNES, Y.R.F. 2018. Changes in species composition, vegetation structure, and life forms along an altitudinal gradient of rupestrian grasslands in south-eastern Brazil. Flora Morphol. Distrib. Funct. Ecol. Plants 32-42.

SMITH, T.W. \& LUNDHOLM, J.T. 2010. Variation partitioning as a tool to distinguish between niche and neutral processes. Ecography (Cop.) 33(4):648-655.

TITLE, P.O. \& BEMMELS, J.B. 2018. ENVIREM: an expanded set of bioclimatic and topographic variables increases flexibility and improves performance of ecological niche modeling. Ecography (Cop.).

ULRICH, W. \& GOTELLI, N.J. 2007. Null model analysis of species nestedness patterns. Ecology 88(7):1824-1831.

VELOSO, H.P., RANGEL FILHO, A.L.R. \& LIMA, J.C.A. 1991. Classificação da vegetação brasileira adaptada a um sistema universal. Instituto Brasileiro de Geografia e Estatística, Rio de Janeiro.

WAECHTER, J.L. 2007. Distribuição de bromeliáceas epifíticas em florestas do Rio Grande do Sul. In A Botânica no Brasil: pesquisa, ensino e políticas públicas ambientais. (L. S. J. N. Barbosa, ed.) Sociedade Botânica do Brasil, São Paulo, p.450-454.

WINKLER, S. 1982. Die Bromeliaceae von Rio Grande do Sul. Doc. Naturae 31-90.

ZELLWEGER, F., ROTH, T., BUGMANN, H. \& BOLLMANN, K. 2017. Beta diversity of plants, birds and butterflies is closely associated with climate and habitat structure. Glob. Ecol. Biogeogr. 26(8):898-906.

Received: $29 / 07 / 2019$

Revised: $30 / 09 / 2019$

Accepted: 08/11/2019

Published online: 24/01/2020 